\title{
Epidemiology and genetic characterization of BVDV, BHV-1, BHV-4, BHV-5 and Brucella spp. infections in cattle in Turkey
}

\author{
Muhammet Eren ASLAN ${ }^{1)}$, Ahmet Kursat AZKUR ${ }^{1) *}$ and Serkal GAZYAGCI ${ }^{2)}$ \\ ${ }^{1)}$ Department of Virology, Faculty of Veterinary Medicine, Kirikkale University, Kirikkale 71450, Turkey \\ ${ }^{2)}$ Department of Internal Medicine, Faculty of Veterinary Medicine, Kirikkale University, Kirikkale 71450, Turkey
}

(Received 12 December 2014/Accepted 21 May 2015/Published online in J-STAGE 21 June 2015)

ABSTRACT. The aim of the study was to determine the epidemiological data of bovine viral diarrhea virus (BVDV), bovine herpesvirus-1 (BHV-1), bovine herpesvirus-4 (BHV-4), bovine herpesvirus-5 (BHV-5) and Brucella-associated cattle that were previously reported to have abortion and infertility problems in Ankara, Corum, Kirikkale and Yozgat provinces, Turkey. Whole blood and sera samples were obtained from 656 cattle, and antibodies against Brucella spp. were detected in 45 (6.86\%) and 41 (6.25\%) animals by Rose Bengal plate and serum tube agglutination tests, respectively. The seropositivity rates against BVDV, BHV-1 and BHV-4 were $70.89 \%, 41.3 \%$ and $28.78 \%$, respectively. RT-PCR and PCR were performed to detect RNA and DNA viruses in blood samples, respectively. The BVDV 5'-untranslated region and BHV-1 gB gene detected in this study were phylogenetically analyzed. The BVDV strains analyzed in this study were closely related to those previously reported from Turkey. The nucleotide sequence from the BHV-1 strain detected in this study is the first nucleotide sequence of BHV-1 circulating in this area of Turkey deposited in the GenBank. The presence of Brucella spp. and prevalence of BHV-1, BHV-4 and BVDV in cattle should be further investigated throughout these regions.

KEY WORDS: abortion agent, cattle, phylogenetic analysis, seroprevalence

doi: 10.1292/jvms.14-0657; J. Vet. Med. Sci. 77(11): 1371-1377, 2015

Abortion, neonatal deaths and infertility-related production losses have been attributed to viruses, bacteria, protozoa, fungal infections and noninfectious factors, such as genetic, hormonal and metabolic disorders and feeding problems [40].

Brucellosis is one of the most widespread zoonotic bacterial diseases that harms humans, domestic and wild ruminants and other animals in many countries around the world [38]. Brucella spp. are Gram-negative, aerobic, facultative intracellular coccobacilli or short rods [19]. Brucellosis in cattle is usually caused by $B$. abortus, and B. melitensis and $B$. suis are occasionally associated with abortion in the last trimester of gestation. The symptoms of brucellosis include reduced milk production, increase in number of somatic cells in milk, impaired reproductive efficiency, weak fetus and infertility both in males and females $[55,56]$. The Rose Bengal plate test (RBPT), serum tube agglutination test (STAT), ELISA and complement fixation test (CFT) are suitable diagnostic tests for brucellosis [18].

Pestivirus is a genus within the family Flaviviridae, which includes bovine viral diarrhea virus 1 and 2 (BVDV-1 and BVDV-2) species [7, 25]. BVDV is an enveloped virus containing a single-stranded positive-sense RNA molecule with a length of $12.3 \mathrm{~kb}$ and a single open reading frame (ORF) flanked by 5'- and 3'-untranslated regions (UTRs)

*Correspondence to: Azkur, A. K., Department of Virology, Faculty of Veterinary Medicine, Kirikkale University, Kirikkale 71450, Turkey. e-mail: azkurkursat@hotmail.com (C)2015 The Japanese Society of Veterinary Science

This is an open-access article distributed under the terms of the Creative Commons Attribution Non-Commercial No Derivatives (by-nc-nd) License $<$ http://creativecommons.org/licenses/by-nc-nd/3.0/>.
[51]. The most common economic losses resulting from BVDV infection are associated with failure in fertilization, abortion, congenital malformation, stillbirth or birth of persistently infected (PI) progeny $[21,43]$. The seroprevalence rates vary between $46-86 \%$, and $0.07-4.9 \%$ of animals were reported to be PI in Turkey $[1,13,14,45,46,58]$.

Bovine herpesvirus-1 (BHV-1) belongs to the genus Varicellovirus in the subfamily Alphaherpesvirinae under the family Herpesviridae, and its viral genome consists of double-stranded DNA of approximately $135 \mathrm{~kb}$ in length $[25,34]$. BHV-1 has been found to infect a number of artiodactyl species and is closely related to viruses infecting other domestic and wild ungulates [49]. BHV-1 can become latent following a primary infection with a field isolate or vaccination with an attenuated strain. Latency occurs in sensory neurons within trigeminal ganglia and also in nonneural sites (tonsillar lymphoid cells, peripheral blood and lymph nodes) $[11,35]$. Reactivation of a latent infection can occur due to stressful conditions, such as transport and parturition and the application of corticosteroids [36]. The BHV-1 seropositivity rates among cattle were reported to be between 9.25 and $74 \%$ in different regions of Turkey $[4,5,47]$.

Bovine herpesvirus 5 (BHV-5), which belongs to the genus Varicellovirus, has an approximately $138 \mathrm{~kb}$ long DNA genome that is responsible for meningoencephalitis in young cattle and is closely related to BHV-1 both antigenically and genetically $[17,25]$. It was reported that cross-reactivity occurs with BHV-5 after BHV-1 vaccination and that BHV-5 cannot be discriminated from BHV-1 with ELISA tests $[9,15,48]$. Recently, it was reported that BHV-5 plays an important role in venereal diseases and infertility in cattle [31], although there have been scientific reports of BHV5 -associated infections or outbreaks in Turkey so far. 
Table 1. Primers used for RT-PCR and PCR in this study

\begin{tabular}{|c|c|c|c|c|}
\hline Virus & Primer Name & $5^{\prime} \rightarrow 3^{\prime}$ & $\begin{array}{l}\text { Length of } \\
\text { base pair }\end{array}$ & Reference \\
\hline \multirow[t]{2}{*}{ Pan-Pestivirus } & 324 & ATGCCCWTAGTAGGACTAGCA & $288 \mathrm{bp}$ & {$[52]$} \\
\hline & 326 & TCAACTCCATGTGCCATGTAC & & \\
\hline BVDV-1a & $1 \mathrm{AF}$ & TCGACGCCTTRRCATGAAGGT & $169 \mathrm{bp}$ & [42] \\
\hline BVDV-1b & $1 \mathrm{BF}$ & TCGACGCTTTGGAGGACAAGC & & \\
\hline BVDV- $1 \mathrm{a} / 1 \mathrm{~b}$ & $1 \mathrm{ABR}$ & CCATGTGCCATGTACAG & & \\
\hline \multirow[t]{2}{*}{ BVDV-2 } & B5 & ACTAGCGGTAGCAGTGAG & $221 \mathrm{bp}$ & {$[33]$} \\
\hline & B6 & CTAGCGGAATAGCAGGTC & & \\
\hline \multirow[t]{2}{*}{ BHV-1 } & BHV-1gB1 & AAGCGCAAAAACGTGTG & $323 \mathrm{bp}$ & {$[44]$} \\
\hline & BHV-1gB2 & TGCAGGTACAGCTTGGC & & \\
\hline \multirow[t]{2}{*}{ BHV-4 } & BHV-4gB1 & СССТТСТТТАССАССАССТАСА & $615 \mathrm{bp}$ & {$[54]$} \\
\hline & BHV-4gB2 & TGCCATAGCAGAGAAACAATGA & & \\
\hline \multirow[t]{2}{*}{ BHV-5 } & BHV-5gD1 & GCCCGCAGTTTCCCCTACC & 564 bp & [2] \\
\hline & $\mathrm{BHV}-5 \mathrm{gD} 2$ & CGCACCCGCTCTCAATCTT & & \\
\hline
\end{tabular}

Bovine herpesvirus 4 (BHV-4), which belongs to the Herpesviridae family and is a member of the Gammaherpesvirinae subfamily and Rhadinovirus genus, is widespread around the globe in cattle populations [25]. The virus has been frequently isolated from healthy individuals and from cattle with a wide variety of clinical signs [24, 26, 29, 53]. The BHV-4 seroprevalence in cattle reportedly ranges between 20.22 and $84.37 \%$ in some countries, including Turkey $[5,10,20,22,28$, $36,58]$. This study aimed to determine the seroprevalence and genetic characteristics of BVDV, BHV-1, BHV-4 and BHV-5 infections in cattle populations negative for Brucella spp. in Ankara, Corum, Kirikkale and Yozgat provinces, Turkey.

\section{MATERIALS AND METHODS}

Sample collection: Samples were mainly collected in Kirikkale [(39॰50' N; 333 ' 'E; altitude $700 \mathrm{~m})$ ]. There were 45,664 dairy cattle in Kirikkale and approximately 13,000 cattle over 15 months of age. A low rate of abortions is usually observed on farms, and 3 abortions per 100 pregnancies per year are often considered a "normal" fertility rate. The blood samples were collected from 390 dairy cattle over 15 months of age with a history of abortion and/or infertility from randomly selected herds in Kirikkale Province.

The remaining blood samples were collected in Ankara (39 $56 \mathrm{~N}$; $32^{\circ} 52^{\prime} \mathrm{E}$; altitude $870 \mathrm{~m} ; \mathrm{n}=91$ ), Corum (39 $14^{\prime}$ ' $\mathrm{N} ; 38^{\circ} 27^{\prime} \mathrm{E}$; altitude $810 \mathrm{~m}$; $\left.\mathrm{n}=86\right)$ and Yozgat $\left(39^{\circ} 50 \mathrm{~N}\right.$; $34^{\circ} 48^{\prime} \mathrm{E}$; altitude $1418 \mathrm{~m} ; \mathrm{n}=89$ ) provinces, which all border Kirikkale Province.

Whole blood samples were collected into EDTA-coated tubes and stored in $-20^{\circ} \mathrm{C}$ until RNA or DNA isolation. Blood samples were collected into tubes without an anticoagulant for separation of serum, allowed to clot at room temperature and centrifuged at 2,000 rpm for $10 \mathrm{~min}$. Serum was collected and kept at $-20^{\circ} \mathrm{C}$ until use.

Serological tests for detection of brucellosis: RBPT and STAT were performed according to the procedures described by the manufacturer of the kits (Pendik Institute, Istanbul, Turkey). The STAT was considered positive, if there were any signs of agglutination in the RBPT and the titer was $\geq 1: 80$.

ELISA: Commercial ELISA kits were used according to the manufacturers' instructions to detect the antibodies against BVDV (BVDV Ab ELISA, Idexx, Westbrook, ME, U.S.A.), BHV-1 (Herdchek IBR gE, Idexx) and BHV-4 (BIO-X Diagnostics, Rochefort, Belgium) and the antigen of BVDV (ELISA BVD/MD Antigen Mix Screening, Institut Pourquier, Montpellier, France). Optical densities at appropriate wavelengths were measured by an automated ELISA reader (SIRIO S ${ }^{\circledR}$ Elisa Reader, ReiGed Diagnostics, Jakarta, Indonesia).

PCR and RT-PCR: To detect the BHV-1, BHV-4 or BHV5 gene, DNA was extracted from blood using a spin column system (High Pure PCR Template Preparation, Roche, Mannheim, Germany) according to the manufacturer's instructions.

To detect the BHV-1 gB, BHV-4 gB and BHV-5 gD genes, PCR was performed with the primers shown in Table 1 . The mixture for all PCR reactions contained $5 \mu l$ DNA, $25 \mathrm{mM}$ Tris- $\mathrm{HCl}$ (pH 8.9), 3 mM MgCl 2 (MBI Fermentas, Vilnius, Lithuania), $2 \mathrm{mM}$ of dNTP mix (MBI Fermentas), $10 \mathrm{pmol}$ of each primer and $1 \mathrm{U}$ of Taq DNA polymerase (MBI Fermentas). The reaction conditions for PCR were as follows: $95^{\circ} \mathrm{C}$ for $2 \mathrm{~min} ; 35$ cycles of $95^{\circ} \mathrm{C}$ for $30 \mathrm{sec}, 58^{\circ} \mathrm{C}, 56^{\circ} \mathrm{C}$ or $59^{\circ} \mathrm{C}$ for $30 \mathrm{sec}(\mathrm{BHV}-1 \mathrm{gB}), 45 \mathrm{sec}(\mathrm{BHV}-4 \mathrm{gB})$ or $1 \mathrm{~min}$ (BHV-5 gD), respectively, and $72^{\circ} \mathrm{C}$ for $30 \mathrm{sec}$; and finally $72^{\circ} \mathrm{C}$ for $10 \mathrm{~min}$.

To detect BVDV gene, RNA was extracted from blood using a spin column system (High Pure Viral RNA Kit, Roche) according to the manufacturer's instructions. cDNA synthesis and RT-PCR were performed according to Sarikaya et al. [45] with the primers shown in Table 1.

All PCR or RT-PCR reactions were carried out in a BOPCR-5 thermal cycler (Boeco, Hamburg, Germany). An InGenius LHR (Syngene, Cambridge, U.K.) was used to visualize PCR amplicons after electrophoresis in 1\% agarose gel and ethidium bromide staining.

Nucleotide sequence analysis and accession numbers: Amplified fragments were purified from agarose using a GeneClean III Kit (MP Biomedicals, Illkirch-Graffenstaden, 
$\underline{\mathbf{A}}$

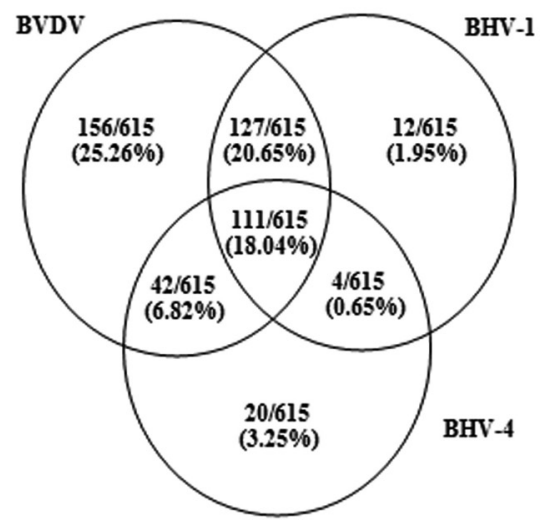

$\underline{\mathbf{B}}$

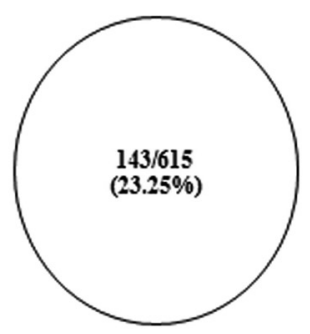

Fig. 1. The seropositivity rates of BHV-1, BHV-4 and BVDV infections in cattle sera. A, single-, double- and triple-positive samples; B, samples seronegative for BVDV, BHV-1 and BHV-4.

France) following the manufacturer's instructions. Direct sequencing of the DNA fragments was performed for each PCR product by a commercial company (Iontek, Istanbul, Turkey). Nucleotide sequences were compared with analysis software (MEGA 6 and Clustal Omega). The nucleotide sequences were deposited in the GenBank database under the accession numbers for BVDV (Fig. 2) and BHV-1 (Fig. 3).

\section{RESULTS}

Whole blood and serum samples were collected from a total of 656 cows in Ankara $(n=91)$, Corum $(n=86)$, Kirikkale $(n=390)$ and Yozgat $(n=89)$ provinces. Forty-five of 656 serum samples $(6.86 \%)$ were found to be positive for Brucella spp. by RBPT, and all RBPT-positive serum samples were confirmed by STAT to determine their titers. The titers of 41 of the 656 serum samples $(6.25 \%)$ were found to be $\geq 1 / 80$. A total of 615 serum samples (excluding sera positive for Brucella spp.) were further tested with ELISA to determine the seropositivity rate against BVDV, BHV-1 and BHV-4.

The ELISA seropositivity rate for BVDV was $70.89 \%$ (436/615) (Table 2). There was limited information about vaccination against BHV-1 in the cattle herds randomly included in the study. Accordingly, all animals were considered vaccinated, and BHV-1 gE ELISA was used to distinguish naturally infected cattle from vaccinated cattle. The BHV-1 seropositivity rate was $41.3 \%$ (254 out of 615 ) (Table 2 ). The seropositivity rate detected for BHV-4 was $28.78 \%$ (177 out of 615) (Table 2).

For genotypic determination of BVDV, a total of 506 whole blood samples (436 antibody positive and 70 antigen positive by ELISA) were subjected to RT-PCR, and 18 (3.55\%) of them were positive (Table 2 ). When a second round of PCR was carried out with internal primers for determination of subtypes BVDV 1a, BVDV 1b and BVDV-2, no amplicons were observed. For genome detection of BHV-1, PCR was carried out in 254 seropositive samples, and $1(0.39 \%)$ whole blood sample was found to be positive (Table 2). PCR was performed to test $177 \mathrm{BHV}-4$ seropositive samples for $\mathrm{BHV}$ -
4 and 254 BHV-1 seropositive samples for BHV-5, and no amplicons were observed for BHV-4 and BHV-5 (Table 2).

The prevalences were calculated depending on the provinces in which the serum samples were collected. The seropositivity rates in Kirikkale were 316/365 (85.47\%) for BVDV, 189/365 (51.78\%) for BHV-1 and 107/365 (29.31\%) for BHV-4. The seropositivity rates in Yozgat were $97.46 \%$ (77/79), 79.74\% (63/79) and 62.02\% (49/79) for BVDV, BHV-1 and BHV-4, respectively. In Ankara, ELISA revealed that $43.02 \%(37 / 86), 2.32 \%(2 / 86)$ and $24.41 \%(21 / 86)$ of the samples were positive for BVDV, BHV-1 and BHV-4, respectively. The seropositivity rate for BVDV in Corum was $6 / 85(7.05 \%)$, and no specific antibody was detected for BHV-1 and BHV-4 (Table 3).

No antibody response against BVDV, BHV-1 or BHV-4 was observed for 143 of $615(23.25 \%)$ samples (Fig. 1B). However, 111 of 615 (18.04\%) samples had antibodies against three of the viruses in combination. The rates of double positivity for BVDV/BHV-1, BVDV/BHV-4 and BHV-1/BHV-4 were $20.65 \%$ (127/615), 6.82\% (42/615) and $0.65 \%$ (4/615), respectively (Fig. 1A).

A phylogenetic tree of BVDV was generated by comparison of the nucleotide sequences between the previously reported 5'-UTR of the pestivirus genome and our study. The nucleotide sequences found in this study have the highest sequence similarity with HQ393488 and the lowest sequence similarity with GU979818 (Fig. 2). The BHV-1 sequence was deposited in GenBank under accession number KF716130.1. According to phylogenetic analysis, the sequence obtained in this study showed the highest similarity to the reported sequences EF175730.1 and KF584168.1 of the BHV-1 gB gene deposited in GenBank (Fig. 3).

\section{DISCUSSION}

The livestock industry is severely affected by production losses due to abortion, neonatal deaths and infertility, which can be prevented by investigations of the causing infections. This study shows that BVDV, BHV-1, BHV-4 and BHV-5 


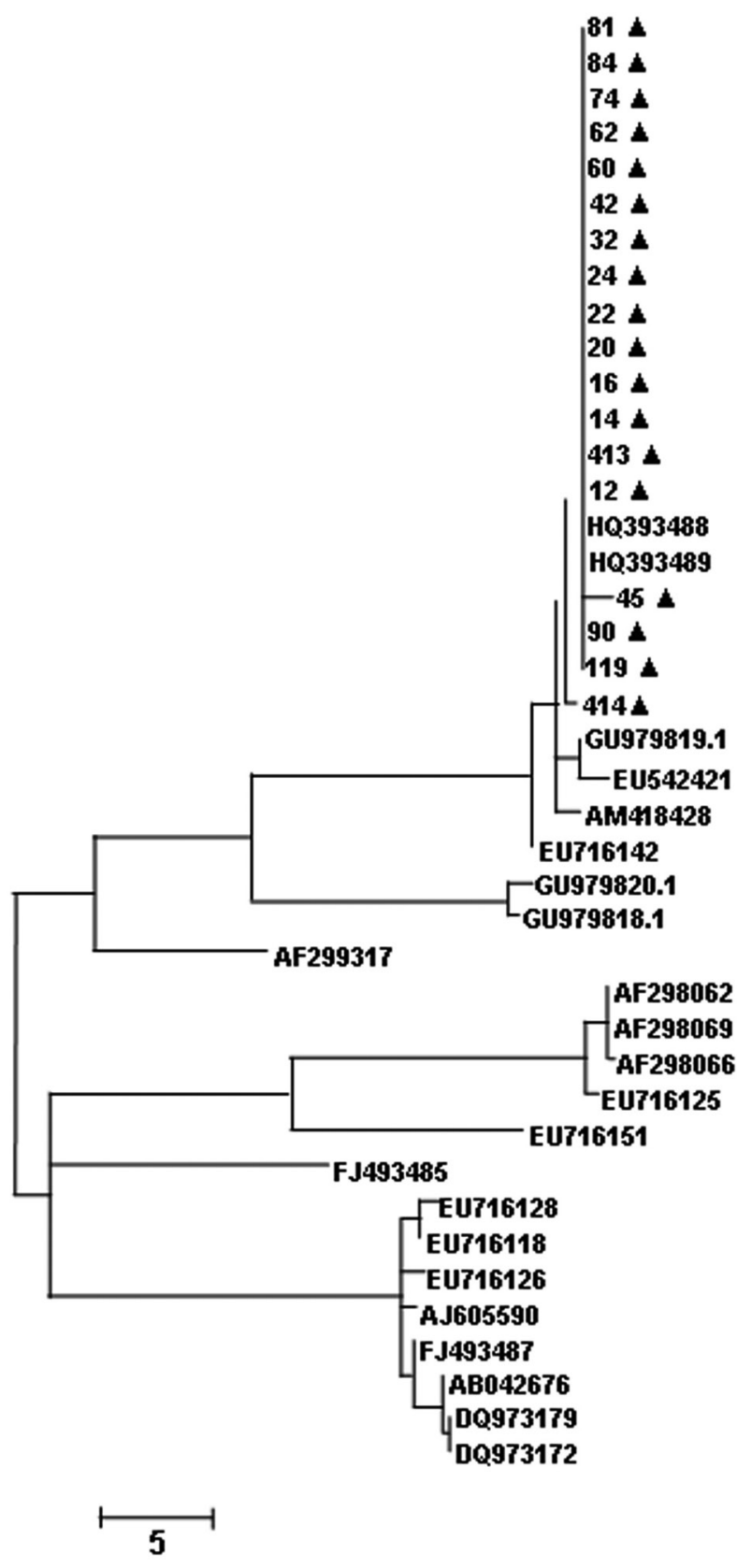

Fig. 2. BVDV phylogenetic analysis. The phylogenetic maximum likelihood tree for the $5^{\prime}$-UTR of the pestivirus genome was generated by using the MEGA 6 software. Sequences generated in this study were as follows: 119-KF425303, 74-KF434627, 60-KF434625， 62-KF434626， 32-KF434623， 24-KF434622, 22-KF434621， 20-KF434620， 14-KF434618， 16-KF434619, 12-KF425300，45-KF425299，413-KF425302，414-KF425301, 90-KF434630, 84-KF434629, 81-KF434628 and 42-KF434624. Sequences not generated in this study were derived from GenBank and were as follows: HQ393488, HQ393489, EU716142, EU716128, DQ973179, EU716151, AF298062, EU716126, AF298069, AF298066, FJ493485, AF299317, EU716118, DQ973172 and EU716125 for BVDV-1; EU542421 and AB042676 for BVDV-2; AM418428, FJ493487, GU979820.1, GU979819.1 and GU979818.1 for BDV; and AJ605590 for CSFV.

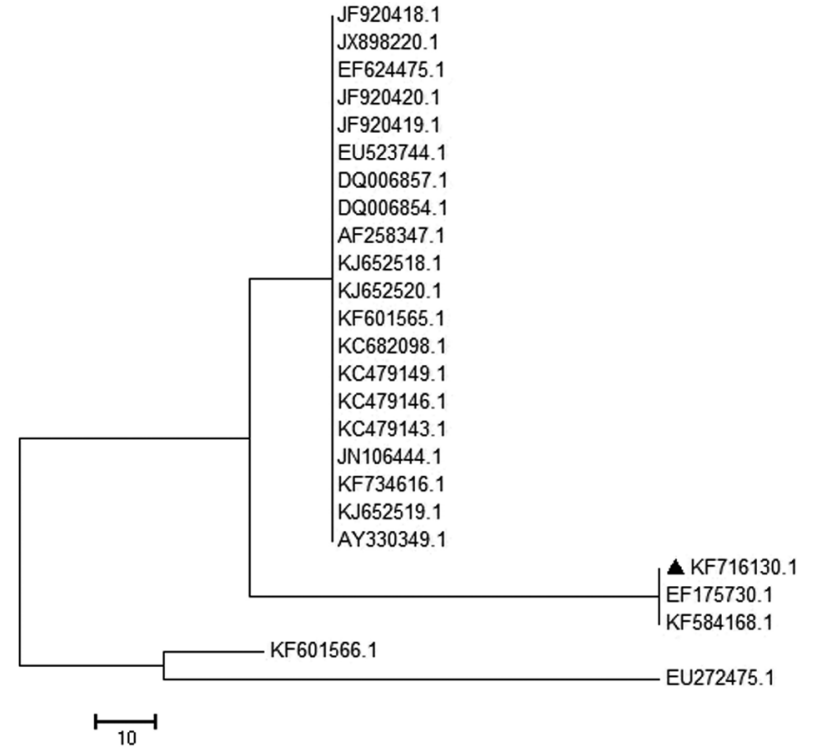

Fig. 3. The phylogenetic tree for the gB gene of BHV-1. The phylogenetic tree was inferred using the MEGA 6 and Clustal omega softwares. Sequences (EF175730.1, KJ652520.1, KJ652518.1, KF584168.1, KC479146.1, KF601566.1, KF601565.1, KC479149.1, KC479143.1, JF920419.1, DQ006854.1, KF734616.1, KC682098.1, JN106444.1, AY330349.1, EU272475.1, JF920420.1, JF920418.1, EU523744.1, AF258347.1, DQ006857.1, EF624475.1, KJ652519.1 and JX898220.1) were not generated by this study, but were derived from GenBank for the KF716130.1 sequence.

may play an important role in genital disorders and abortions in cattle in Ankara, Corum, Kirikkale and Yozgat provinces, Turkey.

Although noninfectious factors, such as genetic, hormonal and metabolic disorders, feeding problems and unsuitable vaccination programs, cause reproductive problems, most of the reported main factors for abortion, neonatal death and infertility are still due to viral, bacterial, protozoal and fungal infections [39]. The abortions and stillbirths of 8,995 cattle were investigated over a 10-year period, and 2,723 $(30.38 \%)$ of the abortions were determined to have resulted from infectious agents, while 219 (2.44\%) cases were the result of noninfectious causes. The rates of abortion caused by infection with viruses, bacteria and fungi were $10.57 \%$, $14.49 \%$ and $5.31 \%$, respectively. The etiology of the remaining $6,020(67.17 \%)$ abortions could not be determined [30]. At the end of 2011, Schmallenberg virus was announced as a prevalent novel virus that causes abortions in European countries as well as Turkey $[6,23]$. Another recently discovered virus, HoBi-like virus, was also found to be a reason for cattle abortions and neonatal deaths [8]. These recently discovered viruses could have played a role in undetermined abortions reported in previous studies.

In this study, we aimed to focus on viral agents, as there was limited information regarding the sampling area and cause of genital disorders (abortion, infertility, etc.). Samples seropositive for Brucella were excluded, and a total of 615 
Table 2. Seroprevalence rates for BVDV, BHV-1 and BHV-4 in serum samples negative for Brucella spp. The values represent the numbers of seropositive samples detected by RT-PCR and the numbers of PCR-positive samples

\begin{tabular}{ccc}
\hline \multirow{2}{*}{ Virus } & \multicolumn{2}{c}{ Prevalence (\%) } \\
\cline { 2 - 3 } & Antibodies & Gene \\
\hline BVDV & $436 / 615(70.89 \%)$ & $18 / 506(3.55 \%)$ \\
BHV-1 & $254 / 615(41.3 \%)$ & $1 / 254(0.39 \%)$ \\
BHV-4 & $177 / 615(28.78 \%)$ & $0 / 177$ \\
BHV-5 & Not Performed & $0 / 254^{*}$ \\
\hline
\end{tabular}

*PCR performed with 254 BHV-1 seropositive samples for BHV-5

negative serum samples were tested with commercial ELISA kits to detect specific antibodies for BVDV, BHV-1 and BHV-4. In our study, it was determined that the rate of BVDV seropositivity was $70.89 \%$ (436 out of 615 ) by ELISA, and $3.55 \%$ (18 out of 506 ) of whole blood samples were positive for the BVDV gene. The seropositivity and antigen (or genome) rates for BVDV were $46.22-86 \%$ and $2.3-4.9 \%$ in previous studies of cattle in Turkey, respectively [3, 46, 58].

BVDV-1 and BVDV-2 have been reported in many countries around the world, and BVDV-1a, 1b, 1d, 1f, 1h, 1g and 2a genotypes have already been reported in Turkey [27, 37, 39, 41]. Sarikaya et al. [45] investigated the genetic variability in the 5'-UTR of BVDV from samples obtained from Kirikkale and detected BVDV-1a (0.625\%) and BVDV-2 (7.5\%). In this study, BVDV subtypes (BVDV 1a, BVDV 1b and BVDV-2) were investigated with internal primers, but no amplicons were detected. The observed difference between this study and that of Sarikaya et al. [45] suggested that the BVDV circulating among the cattle in the study area showed high relatedness according to phylogenetic analyses, although there was a difference in genotype. Hence, although there is a high relatedness between the circulating strains, we speculated that there could be other genotypes besides BVDV 1a, BVDV 1b and BVDV-2 in this area. According to phylogenetic analysis, the BVDV sequences determined in this study were close to those of BVDV-1 previous reported in Kirikkale, Turkey.

The gE blocking ELISA is suitable for differentiating between infected cattle and cattle vaccinated with a gE-negative vaccine [50]. Comparison of the gE-ELISA with the highly sensitive gB-ELISA revealed a relative specificity of $99 \%$ and a relative sensitivity of $92 \%$ [32]. In the present study, the seropositivity rate for BHV-1 was $41.3 \%$ by gE blocking ELISA. Previous studies reported a seropositivity rate for BHV-1 of between $9.25-74 \%$ in Turkey [4, 5, 12, 39].

The prevalences of BVDV, BHV-1 and BHV-4 were higher in Kirikkale and Yozgat in comparison with Ankara and Corum. The blood samples were collected from dairy cattle herds managed by an intensive cattle production system in Ankara and Corum, while they were randomly collected in Kirikkale and Yozgat. The observed results suggested that the intensive cattle production systems may be a limiting factor for the circulation of viral agents amongst dairy cattle farms.

Analysis of overlapping seroprevalence showed that the rates of double positivity were $20.65 \%$ for BVDV/BHV-1,
Table 3. Seroprevalence of BVDV, BHV-1 and BHV-4 in serum samples negative for Brucella spp. according to the provinces sampled

\begin{tabular}{lccc}
\hline \multirow{2}{*}{ Province } & \multicolumn{3}{c}{ Prevalence (\%) } \\
\cline { 2 - 4 } & BVDV Ab $(+)$ & BHV-1 Ab $(+)$ & BHV-4 Ab $(+)$ \\
\hline Kirikkale & $316 / 365(86.57 \%)$ & $189 / 365(51.78 \%)$ & $107 / 365(29.31 \%)$ \\
Corum & $6 / 85(7.05 \%)$ & $0 / 85$ & $0 / 85$ \\
Yozgat & $77 / 79(97.46 \%)$ & $63 / 79(79.74 \%)$ & $49 / 79(62.02 \%)$ \\
Ankara & $37 / 86(43.02 \%)$ & $2 / 86(2.32 \%)$ & $21 / 86(24.41 \%)$ \\
\hline
\end{tabular}

$6.82 \%$ for BVDV/BHV-4 and $0.65 \%$ for BHV-1/BHV-4. The seroprevalence rates for BVDV, BHV-1 and BHV-4 in cattle with abortion problems were previously reported as rates of double seropositivity for BHV-1/BVDV (23.6\%) and BHV-1/BHV-4 (6.4\%) [57]. Furthermore, the highest rates of double seropositivity in other studies were $40.2 \%$ [39] and 33.33\% [5] for BHV-1/BVDV. Thus, it was speculated that the abortion and infertility problems in cattle were mainly caused by BHV-1 and BVDV together. BHV-1 can become latent following a primary infection with a field isolate or vaccination with an attenuated strain in sensory neurons and in non-neural sites [11,35]. Stressful conditions, such as transport and parturition and the application of corticosteroids, can be reasons for reactivation of a latent infection [36]. In this study, detection of the BHV-1 gB gene was carried out in 254 samples found to be seropositive for BHV-1, and only one out of $254(0.39 \%)$ whole blood samples was detected as positive by PCR. BHV-1 circulating in this area was genetically close to BHV-1 isolates reported in India (EF175730.1) and Israel (KF584168.1). This is the first nucleotide sequence of BHV-1 circulating in this area of Turkey to be deposited in GenBank.

Calves up to 6 months of age are sensitive for BVH-5 compared with adult cattle, and BHV-5 persists in the nervous system or brain tissue after experimental or natural infections [16]. In our study, all anti-BHV-1 antibody-positive samples were tested for the BHV-5 gD gene by PCR, but there were no positive results. Sampling of older cattle could be one of the reasons for BHV-5 negativity in blood samples. On the other hand, BHV-5 could be present in several nervous system tissues during latent infection. Thus, sampling of nervous system tissues could be preferable in future studies to obtain more effective results for detection of BHV-5 infection.

BHV-4 has been identified in cases of vulvovaginitis, endometritis, mastitis and abortion and also from apparently healthy cattle [53]. Several studies reported that the seroprevalence rate for BHV-4 varies between 20.22 and $69.6 \%$ in Turkey $[5,10,22,28,57]$. In our study, the BHV-4 seropositivity rate was $28.78 \%$, and the comparative rates of double seropositivity for BHV-4/BHV-1 and BHV-4/BVDV were $0.51 \%$ and $8.2 \%$, respectively. PCR was performed for 177 samples positive for the BHV-4 antibody, but no amplicons were observed for BHV-4. However, the determined rate of BHV-4 seropositivity may be related to genital system problems in cattle of the study area.

In conclusion, we determined the seroprevalence of Bru- 
cella spp., BHV-1, BVDV and BHV-4, in dairy cattle farms in Ankara, Corum, Kirikkale and Yozgat provinces. Our observed seropositivity rates could be considered important, as these agents may lead to abortion in cattle in this region. A study of the genetic diversity of BVDV and BHV-1 is useful for understanding the field distribution of pestivirus, for epidemiological studies and for establishment of further preventative measures and vaccination programs in Turkey. This study shows the necessity of investigation of these infectious diseases that cause economic losses in dairy farms. Therefore, thorough investigation of these infection agents and genotypic characterization of them in the future are crucial to the design of detailed survey studies and development of control measures.

ACKNOWLEDGMENTS. The BHV-1 (Cooper strain) used as a positive control was kindly provided by Prof. Dr. Hakan Bulut of the Department of Virology, Faculty of Veterinary Medicine, University of Firat, Elazig, Turkey. The BHV-4 and BHV-5 strains used as positive controls were kindly provided by Prof. Dr. Seval Bilge Dagalp and Prof. Dr. Aykut Ozkul, respectively, of the Department of Virology, Faculty of Veterinary Medicine, University of Ankara, Turkey.

\section{REFERENCES}

1. Ak, S., Firat, I., Bozkurt, H. H., Gulyaz, V. and Ak, K. 2002. The prevalence of bovine viral diarrhoea virus (BVDV) infections in cattle and existence of persistently infected cattle in the trakya region. Turk. J. Vet. Anim. Sci. 26: 245-248.

2. Alegre, M., Nanni, M. and Fondevila, N. 2001. Development of a multiplex polymerase chain reaction for the differentiation of bovine herpesvirus-1 and -5. J. Vet. Med. B Infect. Dis. Vet. Public Health 48: 613-621. [Medline] [CrossRef]

3. Alkan, F., Ozkul, A., Bilge-Dagalp, S., Yesilbag, K., Oguzoglu, T. C., Akca, Y. and Burgu, İ. 2000. Virological and serological studies on the role of PI-3 virus, BRSV, BVDV and BHV-1 on respiratory infections of cattle. I, The detection of etiological agents by direct immunofluorescence technique. DTW. Dtsch. Tierarztl. Wochenschr. 107: 193-195. [Medline]

4. Ata, A., Kocamuftuoglu, M., Hasircioglu, S., Kale, M. and Gulay, M. S. 2012. Investigation of relationship between bovine herpesvirus-1 (BHV-1) infection and fertility in repeat breeding dairy cows in family type small dairy farms. Kafkas Univ. Vet. Fak. Derg. 18: 579-583.

5. Avci, O. and Yavru, S. 2013. Investigation of bovine herpesvirus-1, bovine viral diarrhea virus and bovine herpesvirus-4 in a dairy herd with naturally infected in Konya. Eurasian J. Vet. Sci. 29: 82-86.

6. Azkur, A. K., Albayrak, H., Risvanli, A., Pestil, Z., Ozan, E., Yilmaz, O., Tonbak, S., Cavunt, A., Kadı, H., Macun, H. C., Acar, D., Ozenc, E., Alparslan, S. and Bulut, H. 2013. Antibodies to schmallenberg virus in domestic livestock in Turkey. Trop. Anim. Health Prod. 45: 1825-1828. [Medline] [CrossRef]

7. Baker, J. C. 1990. Clinical aspects of bovine virus diarrhoea virus infection. Rev. Sci. Tech. 9: 25-41. [Medline]

8. Bauermann, F. V., Ridpath, J. F., Weiblen, R. and Flores, E. F. 2013. HoBi-like viruses: an emerging group of pestiviruses. $J$. Vet. Diagn. Invest. 25: 6-15. [Medline] [CrossRef]

9. Belknap, E. B., Collins, J. K., Ayers, V. K. and Schulteiss, P. C. 1994. Experimental infection of neonatal calves with neuro- virulent bovine herpes virus type 1.3. Vet. Pathol. 31: 358-365. [Medline] [CrossRef]

10. Bilge-Dagalp, S., Demir, A. B., Gungor, E. and Alkan, F. 2007. The seroprevalence of bovine herpes virus type 4 (BHV4) infection in dairy herds in Turkey and possible interaction with reproductive disorders. Rev. Med. Vet. 158: 201-205.

11. Biswas, S., Bandyopadhyay, S., Dimri, U. and Patra, P. H. 2013. Bovine herpesvirus-1 (BHV-1) - a re-emerging concern in livestock: a revisit to its biology, epidemiology, diagnosis, and prophylaxis. Vet. Q. 33: 68-81. [Medline] [CrossRef]

12. Bulut, H., Risvanli, A., Tonbak, Ş., Gülaçtı, I., Azkur, A. K. and Bolat, Y. 2003. Frequency of bovine herpesvirus 1 infections in cows with repeat breeding. (article in Turkish) Firat Univ. Saglik Bilim. Derg. 17: 23-26.

13. Burgu, I., Alkan, F., Ozkul, A., Yesilbag, K., Karaoglu, T. and Gungor, B. 2003. Control and epidemiology of bovine viral diarrhea virus (BVDV) infection for dairy herds in Turkey. (article in Turkish). Ankara Univ. Vet. Fak. Derg. 50: 127-133.

14. Burgu, I., Alkan, F. and Yesilbag, K. 1999. The prevalence of persistent BVD infection in cattle in Turkey. (article in Turkish). Ankara Univ. Vet. Fak. Derg. 46: 169-177.

15. Cascio, K. E., Belknap, E. B., Schultheiss, P. C., Ames, A. D. and Collins, J. K. 1999. Encephalitis induced by bovine herpesvirus 5 and protection by prior vaccination or infection with bovine herpesvirus 1. J. Vet. Diagn. Invest. 11: 134-139. [Medline] [CrossRef]

16. Del Médico Zajac, M. P., Ladelfa, M. F., Kotsias, F., Muylkens, B., Thiry, J., Thiry, E. and Romera, S. A. 2010. Biology of bovine herpesvirus 5. Vet. J. 184: 138-145. [Medline] [CrossRef]

17. Delhon, G., Moraes, M. P., Lu, Z., Afonso, C. L., Flores, E. F., Weiblen, R., Kutish, G. F. and Rock, D. L. 2003. Genome of bovine herpesvirus 5. J. Virol. 77: 10339-10347. [Medline] [CrossRef]

18. Ficht, T. 2010. Brucella taxonomy and evolution. Future Microbiol. 5: 859-866. [Medline] [CrossRef]

19. Garrity, G., Brenner, D. J., Krieg, N. R. and Staley, J. T. 2005. pp.370-386. Bergey's Manual of Systematic Bacteriology, Springer, New York.

20. Graham, D. A., McNeill, G. J., Calvert, V., Mawhinney, K., Curan, W., Ball, N. W. and Todd, D. 2005. Virological and serological evidence of bovine herpesvirus type 4 in cattle in Northern Ireland. Vet. Rec. 157: 539-543. [Medline] [CrossRef]

21. Grahn, T. C., Fahning, M. L. and Zemjanis, R. 1984. Nature of early reproductive failure caused by bovine viral diarrhea virus. J. Am. Vet. Med. Assoc. 185: 429-432. [Medline]

22. Gür, S. and Dogan, N. 2010. The possible role of bovine herpesvirus type-4 infection in cow infertility. Anim. Sci. J. 81: 304-308. [Medline] [CrossRef]

23. Hoffmann, B., Scheuch, M., Hoper, D., Jungblut, R., Holsteg, M., Schirrmeier, H., Eschbaumer, M., Goller, K. V., Wernicke, K., Fischer, M., Breithaupt, A., Mettenleiter, T. C. and Beer, M. 2012. Novel orthobunyavirus in cattle, Europe, 2011. Emerg. Infect. Dis. 18: 469-472. [Medline] [CrossRef]

24. House, J. A., Wilson, T. M., El Nakashly, S., Karim, L. A., Ismail, L., El Danaf, N., Moussa, A. M. and Ayoub, N. N. 1990. The isolation of lumpy skin disease virus and bovine herpesvirus 4 from cattle in Egypt. J. Vet. Diagn. Invest. 2: 111-115. [Medline] [CrossRef]

25. ICTV. 2013. Virus Taxonomy: Release. International committee on taxonomy of viruses. http://ictvonline.org/virusTaxonomy. asp, Accessed 10 December 2014.

26. Izumi, Y., Tsuduku, S., Murakami, K., Tsuboi, T., Konishi, M., Haritani, M., Kamiyoshi, T., Kimura, K. and Sentsui, H. 2006. Characterization of bovine herpesvirus type 4 isolated from 
cattle with mastitis and subclinical infection by the virus among cattle. J. Vet. Med. Sci. 68: 189-193. [Medline] [CrossRef]

27. Kadir, Y., Christine, F., Barbara, B. W., Zeki, Y., Feray, A., Aykut, O., Ibrahim, B., Sibilina Cedillo, R., Heinz-Jürgen, T. and Matthias, K. 2008. Genetic heterogeneity of bovine viral diarrhoea virus (BVDV) isolates from Turkey: identification of a new subgroup in BVDV-1. Vet. Microbiol. 130: 258-267. [Medline] [CrossRef]

28. Kale, M., Ata, A., Kocamuftuoglu, M. and Hasircioglu, S. 2011. Bovine herpesvirus type 4 (BHV-4) infection in relation to fertility in repeat breeder dairy cows. Acta Vet. (Beogr.) 61: 13-19. [CrossRef]

29. Kaminjolo, J. S., Mugera, G. M. and Rosted, A. F. 1972. Isolation of a herpes-type virus from some tumours of bovine origin. Zentralbl. Veterinarmed. B. 19: 626-632. [Medline] [CrossRef]

30. Kirkbride, C. A. 1992. Etiologic agents detected in a 10-year study of bovine abortions and stillbirths. J. Vet. Diagn. Invest. 4: 175-180. [Medline] [CrossRef]

31. Kirkland, P. D., Poynting, A. J., Gu, X. and Davis, R. J. 2009. Infertility and venereal disease in cattle inseminated with semen containing bovine herpesvirus type 5. Vet. Rec. 165: 111-113. [Medline] [CrossRef]

32. Kramps, J. A., Magdalena, J., Quak, J., Weerdmeester, K., Kaashoek, M. J., Maris-Veldhuis, M. A., Rijsewijk, F. A. M., Keil, G. and van Oirschot, J. T. 1994. A simple, specific, and highly sensitive blocking enzyme-linked immunosorbent assay for detection of antibodies to bovine herpesvirus 1. J. Clin. Microbiol. 32: 2175-2181. [Medline]

33. Letellier, C., Kerkhofs, P., Wellemans, G. and Vanopdenbosch, E. 1999. Detection and genotyping of bovine diarrhea virus by reverse transcription-polymerase chain amplification of the 5' untranslated region. Vet. Microbiol. 64: 155-167. [Medline] [CrossRef]

34. Muylkens, B., Thiry, J., Kirten, P., Schynts, F. and Thiry, E. 2007. Bovine herpesvirus 1 infection and infectious bovine rhinotracheitis. Vet. Res. 38: 181-209. [Medline] [CrossRef]

35. Nandi, S., Kumar, M., Manohar, M. and Chauhan, R. S. 2009. Bovine herpes virus infections in cattle. Anim. Health Res. Rev. 10: 85-98. [Medline] [CrossRef]

36. Nikolin, V. M., Donofrio, G., Milosevic, B., Taddei, S., Radosavljevic, V. and Milicevic, V. 2007. First Serbian isolates of bovine herpesvirus 4 (BoHV-4) from a herd with a history of postpartum metritis. New Microbiol. 30: 53-57. [Medline]

37. Oguzoglu, T. C., Muz, D., Yilmaz, V., Alkan, F., Akca, Y. and Burgu, I. 2010. Molecular characterization of bovine virus diarrhea viruse species 2 (BVDV-2) from cattle in Turkey. Trop. Anim. Health Prod. 42: 1175-1180. [Medline] [CrossRef]

38. OIE. 2009. Bovine brucellosis. Manual of diagnostic tests and vaccines for terrestrial animals. http://www.oie.int/fileadmin/ home/eng/health_standards/tahm/2.04.03_bovine_brucell.pdf Accessed 10 December 2014

39. Ozturk, D., Kale, M., Pehlivanoglu, F., Hasircioglu, S. and Turutoglu, H. 2012. Evaluation for some bacterial and viral abortions of dairy cattle farms in Burdur district of Turkey. Kafkas Univ. Vet. Fak. Derg. 18: 255-258.

40. Peter, A. T. 2000. Abortions in dairy cows: New insights and economic impact. Adv. Dairy Technol. 12: 233-244.

41. Ridpath, J. F. 2010. Bovine viral diarrhea virus: global status. Vet. Clin. N. Am. Food Aust. 26: 105-121.

42. Ridpath, J. F. and Bolin, S. R. 1998. Differentiation of types 1a, $1 \mathrm{~b}$ and 2 bovine viral diarrhoea virus (BVDV) by PCR. Mol. Cell. Probes 12: 101-106. [Medline] [CrossRef]

43. Rüfenacht, J., Schaller, P., Audige, L., Knutti, B., Kupfer, U. and Peterhans, E. 2001. The effect of infection with bovine viral di- arrhea virus on the fertility of Swiss dairy cattle. Theriogenology 56: 199-210. [Medline] [CrossRef]

44. Santurde, G., Da Silva, N., Villares, R., Tabares, E., Solana, A., Bautista, J. M. and Castro, J. M. 1996. Rapid and high sensitivity test for direct detection of bovine herpesvirus-1 genome in clinical samples. Vet. Microbiol. 49: 81-92. [Medline] [CrossRef]

45. Sarikaya, B., Azkur, A. K., Gazyagci, S. and Aslan, M. E. 2012. Genetic variability of bovine viral diarrhea virus in the 5'-UTR in the central anatolia of Turkey. Acta Sci. Vet. 40: 1013.

46. Tan, M. T., Karaoglu, M. T., Erol, N. and Yildirim, Y. 2006. Serological and virological investigations of bovine viral diarrhoea virus (BVDV) infection in dairy cattle herds in Aydin province. Turk. J. Vet. Anim. Sci. 30: 299-304.

47. Tan, M. T., Yildirim, Y., Erol, N. and Gungor, A. B. 2006. The seroprevalence of bovine herpes virus type 1 (BHV-1) and bovine leukemia virus (BLV) in selected dairy cattle herds in Aydin province Turkey. Turk. J. Vet. Anim. Sci. 30: 353-357.

48. Tang, Q., Wu, Y. Q., Chen, D. S., Zhou, Q., Chen, H. C. and Liu, Z. F. 2014. Bovine herpesvirus 5 encodes a unique pattern of microRNAs compared with bovine herpesvirus 1. J. Gen. Virol. 95: 671-678. [Medline] [CrossRef]

49. Thiry, J., Keuser, V., Muylkens, B., Meurens, F., Gogev, S., Vanderplasschen, A. and Thiry, E. 2006. Ruminant alphaherpesviruses related to bovine herpesvirus 1. Vet. Res. 37: 169-190. [Medline] [CrossRef]

50. Van Oirschot, J. T., Kaashoek, M. J., Maris-Veldhuis, M. A., Weerdmeester, K. and Rijsewijk, F. A. 1997. An enzyme-linked immunosorbent assay to detect antibodies against glycoprotein $\mathrm{gE}$ of bovine herpesvirus 1 allows differentiation between infected and vaccinated cattle. J. Virol. Methods 67: 23-34. [Medline] [CrossRef]

51. Vilcek, S., Durkovic, B., Kolesárová, M., Greiser-Wilke, I. and Paton, D. 2004. Genetic diversity of international bovine viral diarrhoea virus (BVDV) isolates: identification of a new BVDV1 genetic group. Vet. Res. 35: 609-615. [Medline] [CrossRef]

52. Vilcek, S., Herring, A. J., Herring, J. A., Nettleton, P. F., Lowings, J. P. and Paton, D. J. 1994. Pestiviruses isolated from pigs, cattle and sheep can be allocated into at least three genogroups using polymerase chain reaction and restriction endonuclease analysis. Arch. Virol. 136: 309-323. [Medline] [CrossRef]

53. Wellenberg, G. J., van der Poel, W. H., van der Vorst, T. J., van Valkengoed, P. H., Schukken, Y. H., Wagenaar, F. and van Oirschot, J. T. 2000. Bovine herpesvirus 4 in bovine clinical mastitis. Vet. Rec. 147: 222-225. [Medline] [CrossRef]

54. Wellenberg, G. J., Verstraten, E. R., Belak, S., Verschuren, S. B., Rijsewijk, F. A., Peshev, R. and van Oirschot, J. T. 2001. Detection of bovine herpesvirus 4 glycoprotein B and thymidine kinase DNA by PCR assays in bovine milk. J. Virol. Methods $\mathbf{9 7}$ 101-112. [Medline] [CrossRef]

55. Xavier, M. N., Costa, E. A., Paixao, T. A. and Santos, R. L. 2009. The genus Brucella and clinical manifestations of brucellosis. Cienc. Rural 39: 2252-2260. [CrossRef]

56. Xavier, M. N., Paixao, T. A., den Hartigh, A. B., Tsolis, R. M. and Santos, R. L. 2010. Pathogenesis of Brucella spp. Open Vet. Sci. J. 4: 109-118. [CrossRef]

57. Yildirim, Y., Yilmaz, V., Kalaycioglu, A. T., Dagalp, S. B., Majarashin, A. R. F., Celebi, O. and Akca, D. 2011. An Investigation of a possible involvement of BVDV, BHV-1 and BHV-4 infections in abortion of dairy cattle in Kars district of Turkey. Kafkas Univ. Vet. Fak. Derg. 17: 879-883.

58. Yilmaz, H., Altan, E., Ridpath, J. and Turan, N. 2012. Genetic diversity and frequency of bovine viral diarrhea virus (BVDV) detected in cattle in Turkey. Comp. Immunol. Microbiol. Infect. Dis. 35: 411-416. [Medline] [CrossRef] 